\title{
16S rRNA-based analysis of bacterial diversity in the microbial flora of the goose intestinal tract ${ }^{*}$
}

\author{
Z.Y. Wang ${ }^{1,3}$, S.R. Shi ${ }^{1,2}$, M.J. Xu' ${ }^{1}$ and H.M. Yang ${ }^{1}$ \\ ${ }^{1}$ College of Animal Science and Technology, Yangzhou University \\ 225009 Yangzhou, Jiangsu Province, P.R. China \\ ${ }^{2}$ Poultry Institute, Chinese Academy of Agricultural Sciences \\ 225003 Yangzhou, Jiangsu Province, P.R. China
}

(Received 15 September 2008; revised version 13 February 2009; accepted 24 June 2009)

\begin{abstract}
The microflora in the gastrointestinal tract of poultry influences digestion, health, and wellbeing. Analysis of poultry gut microflora has been done mainly by culture-based methods. Studies using these techniques have been useful for identification and analysis of specific groups of bacteria, however, the use of enrichment medium precludes even relative quantitation of bacterial species. Recent advances in molecular techniques make it possible to identify different bacterial populations in poultry gastrointestinal tract. In this study, the intestinal microbiota was examined using $16 \mathrm{~S}$ rRNA targeted probes from bacterial DNA isolated from five intestinal sections. DNA from microbial flora of five intestinal sections (duodenum, jejunum, ileum, caecum, colon) of six geese was extracted by lysozyme-SDS-phenol/chloroform and freeze thawing combined method. The predominant bacterial community structure was analysed by Polymerase Chain Reaction (PCR) amplification of the DNA followed by Denaturing Gradient Gel Electrophoresis (DGGE). The results showed that there were common bands in the five tract segments analysed, but also many differential bands. Phylogenetic and similarity analyses of the sequences of the cloned fragments from DGGE revealed that the similarity of 26 clones was over 97\%, others were between $94 \sim 96 \%$, and 19 clones of all were similar to sequences of uncultured bacteria.
\end{abstract}

KEY WORDS: bacterial diversity, microbial flora, intestinal tract, DGGE, geese

\footnotetext{
*Supported by the Scientific and Technical Support Program of "Eleventh Five-Year Plan" of the Ministry of Science and Technology, P.R. China, 2008BADB2B08

${ }^{3}$ Corresponding author: e-mail: dkwzy@263.net or ssr236@163.com
} 


\section{INTRODUCTION}

Studies on the composition of the intestinal tract microbiota of poultry date back to 1901 (Rahner, 1901). Additional studies were carried out in the 1940s (Shapiro and Sarles, 1949), but not until the 1970s were comprehensive surveys attempted by culturing as many of the intestinal bacteria as possible (Barnes, 1979). These studies were technically difficult and extremely time consuming because strict anaerobic conditions had to be maintained, and numerous biochemical differentiation tests had to be carried out. Using such methods, only an estimated 10 to $60 \%$ of the bacteria in the intestinal tract could be cultivated (Barnes, 1979). A more comprehensive overview of the intestinal microbiota of poultry would not only be of interest to basic microbiological ecology but might also be of practical importance. For example, further development of effective competitive exclusion products might be aided by a better understanding of the intestinal microbiota composition.

With the development of molecular biology, different molecular techniques have been used to evaluate the microbial diversity of different ecosystems (Zhu et al., 2002; Scupham et al., 2006). Since Muyzer et al. (1993) firstly used denaturing gradient gel electrophoresis (DGGE) to study complex microbial populations, it developed quickly. In recent years, DGGE, as a molecular fingerprint and the use of $16 \mathrm{~S}$ rRNA sequences to classify and identify microorganisms, have been widely used in microbial diversity (Kawai et al., 2002; Theunissen et al., 2005), including poultry intestinal microbe (Pedroso et al., 2005; Torok et al., 2008). However, most of them were mainly focused on chicken. To the authors' knowledge, at present, there are few reports on the microbial flora of the goose intestinal tract. Therefore, the objective of present study was to investigate the microbial flora of the goose intestinal tract applying DGGE technique.

\section{MATERIAL AND METHODS}

\section{Origin and collection of samples}

Six geese with 25 week age were obtained from the farm where they were raised under the same conditions (including the same diet; Table 1). They were sacrificed by cervical dislocation; the five intestinal sections (duodenum, jejunum, ileum, caecum, colon) were removed aseptically, clamped with forceps, and placed in sterile plastic bags on ice. In the laboratory, the five intestinal sections were cut with sterile scissors and were inverted onto sterile glass rods separately. The intestinal segment contents of six geese were pooled (6 duodenum, 6 jejunum, 6 ileum, 6 caecum, 6 colon). Approximately 1 g of content was 
Table 1. Composition and nutritive value of the diet

\begin{tabular}{|c|c|}
\hline Item & $\mathrm{g} / \mathrm{kg}$ \\
\hline \multicolumn{2}{|l|}{ Ingredient } \\
\hline maize & 650 \\
\hline soyabean meal & 100 \\
\hline lucerne meal & 150 \\
\hline wheat bran & 50 \\
\hline vitamin and trace mineral premix ${ }^{1}$ & 50 \\
\hline \multicolumn{2}{|l|}{ Analysed nutrient } \\
\hline crude protein & 133.9 \\
\hline crude fibre & 54.0 \\
\hline $\mathrm{Ca}$ & 3.2 \\
\hline available $\mathrm{P}$ & 2.4 \\
\hline Metabolizable energy, $\mathrm{MJ} / \mathrm{kg}$ & 11.04 \\
\hline \multicolumn{2}{|c|}{$\begin{array}{l}{ }^{1} \text { provided per kg of premix, mg: vit. A (retinyl acetate) } 6 \text {, vit. } \mathrm{D}_{3} \text { (cholecalciferol) } 0.1125 \text {, vit. } \mathrm{E} \\
\text { (Di- } \alpha \text {-tocopheryl acetate) } 30 \text {, vit. } \mathrm{K} \text { (2-methyl-1,4-naphthoquinone) } 20 \text {, thiamine } 10 \text {, riboflavin } \\
120 \text {, pyridoxine } 20 \text {, vit. } \mathrm{B}_{12} \text { (cobalamin) } 0.2 \text {, nicotinic acid } 600 \text {, pantothenic acid } 180 \text {, folic acid } 10 \text {, } \\
\text { folate } 10 \text {, biotin } 0.8 \text {, I } 10, \text { Se } 6 \text {; g: choline } 7, \mathrm{Fe} 1.2, \mathrm{Cu} 0.2, \mathrm{Mn} 1.9, \mathrm{Zn} 1.8\end{array}$} \\
\hline
\end{tabular}

collected into a centrifuge tube containing $9 \mathrm{ml}$ of sterile phosphate-buffered saline (PBS), pH 7.4, centrifuged at $500 \mathrm{~g}$ for $10 \mathrm{~min}$, and then 12,000 $\mathrm{g}$ for $5 \mathrm{~min}$. The pellet was washed with PBS for several times until the supernatant turned clear, and the supernatant was discarded. The pellet was suspended in PBS, $2 \mathrm{ml}$ cetyltrimethyl ammonium bromide (CTAB) and $2 \%$ mercaptoethanol (ME) and 5\% polyvinylpyrrolidone (PVP) were added and the suspension was then stored at $-20^{\circ} \mathrm{C}$ until DNA extraction.

\section{DNA extraction}

DNA extraction from microbial flora of five goose intestinal tract sections (duodenum, jejunum, ileum, caecum, colon) was extracted by combined lysozymeSDS-phenol/chloroform method (Maniatis et al., 1989) and freeze thawing method (Orisini and Romano-Spica, 2001). Completion of bacterial lysis was verified by microscopic examination. DNA was extracted with phenol-chloroform-isoamyl alcohol (25:24:1) and precipitated with isopropanol or ice-cold ethanol. The extracted DNA was treated with DNase-free RNase (Sigma Chemical Co., St. Louis, MO) at a final concentration of $0.2 \mathrm{mg} / \mathrm{ml}$ at $37^{\circ} \mathrm{C}$ for $15 \mathrm{~min}$, followed by a second phenolchloroform-isoamyl alcohol extraction and isopropanol precipitation. Finally, the DNA pellet was resuspended in TE buffer (10 mM Tris-HCl, 1 mM EDTA, $\mathrm{pH}$ 8.0), stored at $-20^{\circ} \mathrm{C}$, and used as template DNA in PCR to amplify the $16 \mathrm{~S}$ rRNA for DGGE analysis. 
PCR

For amplification of fragments specific of the V6-V8 region (Ovreas et al., 1997) of the 16SrRNA of microorganisms of bacterial domain, the primer pairs F968-GC:5'-CGCCCGGGGCGCGCCCCGGGCGGGGCGGGGGCACGGG GGGAACGCGAAGAACCTTAC-3' and R1401:CGGTGTGTACAAGACCC were used. PCR were conducted in a reaction containing $10 \mathrm{mM}$ dinucleotide triphosphate (dNTP) $2 \mu 1,25 \mathrm{mM} \mathrm{MgCl} 21.5 \mu \mathrm{l}, 10 \mathrm{uM}$ of each primer $0.8 \mu \mathrm{l}, 5 \mathrm{U} / \mu \mathrm{l}$ TaqDNA polymerase $0.2 \mu \mathrm{l}, 2.5 \mathrm{ul}$ of the reaction buffer $10 \times$, and $500 \mathrm{ng}$ of DNA add $\mathrm{ddH}_{2} \mathrm{O}$ to $25 \mu \mathrm{l}$. The amplification was performed according to the following conditions: initial denaturation for $5 \mathrm{~min}$ at $94^{\circ} \mathrm{C} ; 35$ denaturation cycles at $94^{\circ} \mathrm{C}$ for $40 \mathrm{~s}$, annealing at $52^{\circ} \mathrm{C}$ for $40 \mathrm{~s}$, and extension at $72^{\circ} \mathrm{C}$ for $50 \mathrm{~s}$; final extension at $72^{\circ} \mathrm{C}$ for $10 \mathrm{~min}$ in thermocycler and stored at $4^{\circ} \mathrm{C}$. A sample of the PCR products (amplicons) was analysed in a laser densitrometer FluorImage. The products of PCR were stored at $4^{\circ} \mathrm{C}$ until analysis.

\section{Denaturing gradient gel electrophoresis (DGGE)}

Denaturing gradient gel electrophoresis was conducted using the CBS DGGE1001 on $17.7 \mathrm{~cm} \cdot 22 \mathrm{~cm} \cdot 0.75 \mathrm{~mm}$ gels. The sequence-specific separation of the PCR products (the amplicons) was obtained in $7.5 \%(\mathrm{wt} / \mathrm{vol})$ polyacrylamide (acrylamide:bis $37.5: 1)$ gels in $1 \times$ Tris-acetate EDTA buffer $(50 \times$ Tris-acetate EDTA stock solution consisting in $2 \mathrm{M}$ Tris-base, $1 \mathrm{M}$ glacial acetic acid, $50 \mathrm{mM}$ EDTA) containing 40 to $60 \%$ linear denaturant gradient. The $100 \%$ denaturing solution contained $40 \%$ (vol/vol) formamide (Bio-Rad) and $7.0 \mathrm{M}$ urea (Bio$\mathrm{Rad})$. Electrophoresis was performed at a constant voltage of $80 \mathrm{~V}$ at $60^{\circ} \mathrm{C}$ for $15 \mathrm{~h}$. The gels were run, fixed in 10\% acetic acid and glacial acetic acid for $15 \mathrm{~min}$, washed 3 times in deionized water, stained with $0.2 \% \mathrm{AgNO}_{3}$ for $15 \mathrm{~min}$, washed again in deionized water, and coloured with $\mathrm{NaOH}$ till the bands were seen clear. For analysis of the results, a scanner (Microtek Scanmarker 6180) was used.

\section{Cloning, sequencing, and phylogenetic analysis}

Small pieces of DGGE bands were punched from the gel with sterile pipette tips. The pieces then were transferred into $20 \mu \mathrm{lddH_{2 }} \mathrm{O}$ and incubated overnight at $4^{\circ} \mathrm{C}$ to allow diffusion of the DNA, which was amplified with the primer without the GC clamp, and sent to Shanghai Sangon Biological Technology and Service Limited Company for cloning and sequencing. These sequences were then compared to those available in public databases by using BLAST analysis against sequences from the Ribosomal Datebase (http://www.ncbi.nlm.nih.gov/ BLAST/). Quantity one analytic software (Bio-Rad) was used to analyse PCRDGGE banding patterns by measuring migration distance within each lane of the 
gel. The profiles were compared using the coefficient of similarity, Cs (simple matching), which was determined as:

$$
\mathrm{Cs}=2 \mathrm{j} /(\mathrm{a}+\mathrm{b})^{-1}
$$

where: Cs - the similarity index between samples, a - the number of PCR-DGGE bands in lane $1, b$ - the number of PCR-DGGE bands in lane 2 , and $\mathrm{j}$ - the number of common PCR-DGGE bands.

Thus, if 2 profiles are identical, Cs equals $100 \%$, if they are entirely different, Cs equals $0 \%$. Then Neighbor-Joining method of MEGA3.1 was used to build phylogenetic tree (1000 sampling).

\section{RESULTS AND DISCUSSION}

Because of their physiological properties (strict anaerobes, nutritional requirements, etc.), many of microorganisms of the goose intestinal tract are difficult to culture using current cultivation conditions, and are still unknown today. DGGE is a molecular fingerprinting method which could separate PCR-generated DNA products and reveal many of the dominant microbial organisms. DGGE has been widely used in microbial diversity in poultry intestines especially in chicken caecum (Zhu et al., 2002; Pedroso et al., 2005). In our study, DGGE profiles of V6-V8 region of 16S rRNA from content of the five intestinal tract segments were compared (Figure 1). Each of the five intestinal section segment samples was a pool of 6 animal contents. The bacterial community in five intestinal sections of goose was abundant, but there were some differences in the five tract segments because of the number, the intensity and the mobility of the bands. The number of the bands in ileum was the lowest, while the number of the bands in caecum and colon was higher than in other two parts of the tract. There were also common bands in different sections. The intensity of the bands was variable, which meant there were common microorganisms in five tract segments, but the abundance of the microorganisms was different. Coefficient of similarity among the structures of the bacterial community in the five intestinal sections from different lanes was higher than $45 \%$, while lane 1 and 2 had the highest coefficient of similarity (81.6\%; Table 2, based on Figure 1).

Table 2. Coefficient of similarity among the structures of the bacterial community in the 5 intestinal sections from the 16SrRNA V6 -V8 DGGE gels, \%

\begin{tabular}{lcccc}
\hline Lane & Duodenum & Jejunum & Ileum & Caecum \\
\hline Jejunum & 81.6 & & & \\
Ileum & 46.4 & 50.3 & & \\
Caecum & 45.1 & 48.2 & 56.8 & \\
Colon & 52.8 & 49.6 & 57.5 & 63.5 \\
\hline
\end{tabular}




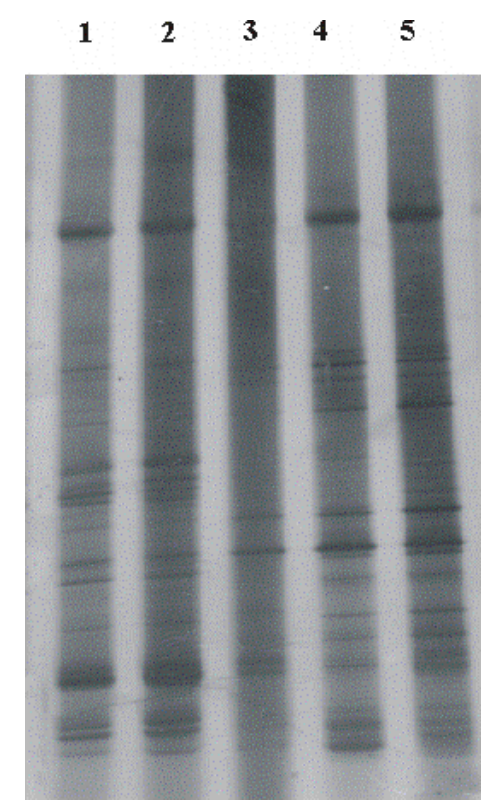

Figure 1. DGGE profiles of five intestinal tract segments (each of the five intestinal tract segment samples was a pool of 6 animal contents) 1 - duodenum, 2 - jejunum, 3 - ileum, 4 - caecum, 5 - colon

Phylogenetic and similarity analyses of the sequences of the cloned DGGE fragments revealed that the similarity of 26 clones was over $97 \%$, others were between 94 96\%, and 19 clones of all were similar to those of uncultured bacteria (Table 3, Figure 2), which indicated that unknown and yet uncultured bacteria were present in goose intestine sections. The dominant bacteria in goose intestine sections, detected from DGGE fingerprints, were the most similar to Pseudomonas sp., Burkholderia sp., Kocuria sp., Rothia sp., Gamma proteobacterium, Clostridium colinum, Bifidobacterium sp. and uncultured bacterium, most of those bacteria could be classified as low-G+C-positive anaerobic bacteria. Some bacteria such as Pseudomonas sp., Clostridium colinum and others are pathogenic bacteria, which could increase mortality of poultry. Gamma proteobacterium belonged to thermophilic bacteria, which could live in elevated temperatures. Bifidobacterium sp., Clostridium colinum and Lactobacillus spp. were also found as the dominant bacteria flora in adult geese by traditional culture method, which in caecum were significantly higher $(\mathrm{P}<0.01)$ than that in the other intestinal segments (Zhang et al., 2007). Early studies involved culturing of bacteria had many limitations in demonstrating the diversity of the microbial flora of the intestinal tract of geese, so the molecular techniques such as DGGE should be combined with culturebased approaches to analyse the microbiota (Xiao et al., 2007) 
Table 3. Sequencing results of the bands cut from the 16SrRNA V6 -V8 DGGE gels

\begin{tabular}{|c|c|c|c|c|}
\hline $\begin{array}{l}\text { Intestinal } \\
\text { tract }\end{array}$ & No. & $\begin{array}{l}\text { Length } \\
\text { bp }\end{array}$ & $\begin{array}{c}\text { Source of the most similar GeneBank } \\
\text { sequence in GeneBank }\end{array}$ & $\begin{array}{l}\text { Similarity } \\
\%\end{array}$ \\
\hline \multirow{13}{*}{ Duodenum } & D1 & 435 & Pseudomonas sp.(AY599720.1) & 99 \\
\hline & D2 & 433 & Uncultured bacterium (EU625478.1) & 94 \\
\hline & \multirow{2}{*}{ D5 } & \multirow{2}{*}{433} & Pseudomonas sp. (AY091598.2) & \multirow{2}{*}{99} \\
\hline & & & Uncultured bacterium (EU625479.1) & \\
\hline & & & Uncultured bacterium (EU460309.1) & \multirow{5}{*}{94} \\
\hline & \multirow{4}{*}{ D6 } & \multirow{4}{*}{435} & Pseudomonas sp. (DQ910416.1) & \\
\hline & & & Bacterium (EF526292.1) & \\
\hline & & & Burkholderia caryophylli (DQ839380.1) & \\
\hline & & & Pseudomonas sp. (AY091598.2) & \\
\hline & \multirow[t]{2}{*}{ D7 } & \multirow[t]{2}{*}{433} & Uncultured bacterium (EU625477.1) & \multirow[t]{2}{*}{99} \\
\hline & & & Bacterium (EF257208.1) & \\
\hline & \multirow{3}{*}{ D8 } & \multirow{3}{*}{435} & Kocuria sp. (FJ210848.1) & \multirow{3}{*}{98} \\
\hline & & & Rothia sp. (DQ822568.1) & \\
\hline \multirow{8}{*}{ Jejunum } & & & Pseudomonas sp. (EF044363.1) & \\
\hline & \multirow[t]{2}{*}{ K4 } & \multirow[t]{2}{*}{432} & Gamma proteobacterium (AY539821.1) & \multirow[t]{2}{*}{95} \\
\hline & & & Uncultured bacterium (EU625477.1) & \\
\hline & \multirow[t]{2}{*}{ K5, K6, K7 } & \multirow[t]{2}{*}{431} & Uncultured bacterium (EU625483.1) & \multirow[t]{2}{*}{99} \\
\hline & & & Uncultured bacterium (FM873092.1) & \\
\hline & \multirow[t]{2}{*}{ K10 } & \multirow[t]{2}{*}{433} & Pseudomonas sp. (EU864269.1) & \multirow[t]{2}{*}{99} \\
\hline & & & Bacterium (EU086570.1) & \\
\hline & K11 & 435 & Uncultured bacterium (EU625484.1) & 99 \\
\hline \multirow{6}{*}{ Ileum } & H1 & 431 & Clostridium colinum (X76748.1) & 98 \\
\hline & $\mathrm{H} 4, \mathrm{H} 5$ & 426 & Uncultured bacterium (DQ810058.1) & 99 \\
\hline & \multirow{2}{*}{ M1 } & \multirow{2}{*}{426} & Uncultured bacterium (EU625504.1) & 99 \\
\hline & & & Bacterium (DQ057481.1) & \\
\hline & M2 & 432 & Uncultured bacterium (EU625499.1) & 97 \\
\hline & M3 & 434 & Uncultured bacterium (EF025229.1) & 98 \\
\hline Caccum & & 428 & Uncultured bacterium (EU625504.1) & 99 \\
\hline Caecum & M4 & 428 & Bacterium (DQ057481.1) & 99 \\
\hline & M11 & 433 & Pseudomonas sp. (AB269776.1) & 97 \\
\hline & МП & 433 & Uncultured bacterium (DQ499977.1) & 91 \\
\hline & M13 & 433 & Bifidobacterium sp. (D86196.1) & 98 \\
\hline & M15 & 435 & Bifidobacterium sp. (AB437361.1) & 99 \\
\hline & $\mathrm{J} 1$ & 428 & Uncultured bacterium (EU625504.1) & 99 \\
\hline & $\mathrm{J} 2$ & 433 & Uncultured bacterium (EU625498.1) & 97 \\
\hline & $\mathrm{J} 3$ & 432 & Uncultured bacterium (EF025252.1) & 97 \\
\hline Colon & $\mathrm{J} 4$ & 425 & Uncultured bacterium (DQ799935.1) & 96 \\
\hline & $\mathrm{J} 6$ & 435 & Uncultured bacterium (DQ303273.1) & 99 \\
\hline & $\mathrm{J} 7, \mathrm{~J} 8$ & 428 & Uncultured bacterium (EU625503.1) & 98 \\
\hline & J9 & 426 & Uncultured bacterium (FM873957.1) & 99 \\
\hline
\end{tabular}

$\mathrm{D}$ - refers to duodenum, $\mathrm{K}$ - refers to jejunum, $\mathrm{H}$ - refers to ileum, M - refers to caecum, J - refers to colon 


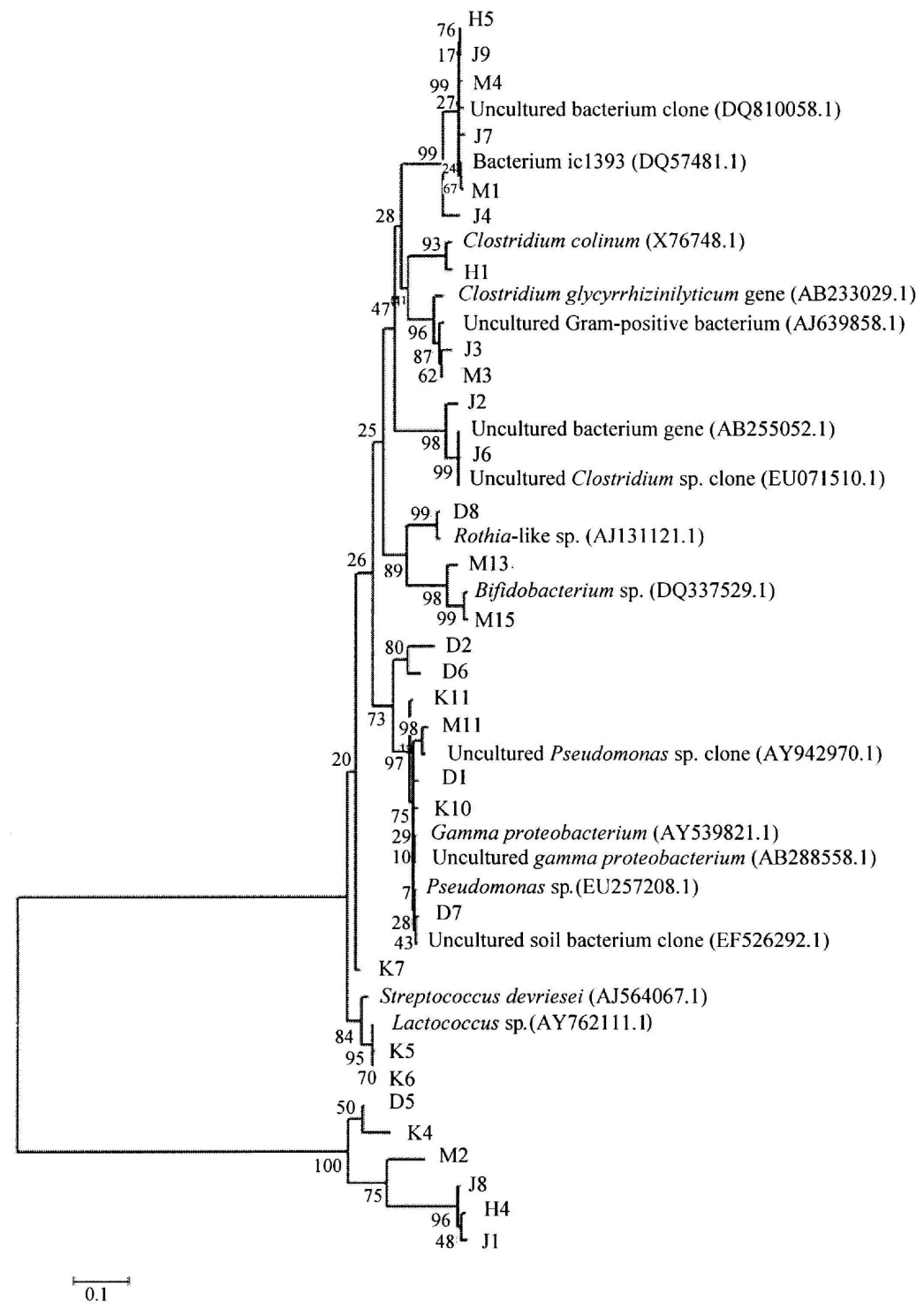

Figure 2. Phylogentic analysis on intestinal bacteria in goose: D - refers to duodenum, $\mathrm{K}$ - refers to jejunum, $\mathrm{H}$ - refers to ileum, $\mathrm{M}$ - refers to caecum, $\mathrm{J}$ - refers to colon. The number at each branch points is the percentage supported by bootstrap bar. 0.1 sequence divergence

Applications of DGGE are widespread in many different ecosystems, but they still have some limitations. They need expensive equipment, different DNA may have similar melting properties, so the addition of a 30-40 bp GC clamp to one 
of the PCR primers is needed (Reeson et al., 2003), while the use of different regions of the 16SrRNA and different DGGE conditions might result in different resolutions of separation. Yu and Morrison (2004) compared and established a preferred choice of $\mathrm{V}$ region(s) to examine by DGGE, and found that DGGE profiles of the V3 region were best, and the V3 to V5 and V6 to V8 regions produced better DGGE profiles than did other multiple V-region amplicons. Other factors than DGGE conditions may also affect the sequence information and PCR amplification, and this implies to optimize the experimental conditions.

Evidence for relatively stable, but distinct intestinal microbiota in ileum and caecum of broiler chickens (Gong et al., 2002) and in caecum of pigs (Robinson and Allison, 1981) was obtained by molecular analyses. Despite such observed individual and interspecies differences in intestinal bacterial populations, some bacterial species are probably common inhabitants of many animal species. Some sequences such as those of Bifidobacterium, Pseudomonas and Lactobacillus species were virtually identical to sequences from other animal or even human sources. On the other hand, the sequence data also suggest that at least part of the bacterial population (Burkholderia sp. usually presented in plant, especially in onion) of the goose intestinal tract might be different from other animal species and unique, also a new sequence "EU625474-EU625504" firstly transmitted to Genbank by us was not found in other species.

\section{CONCLUSIONS}

The results obtained in this study presented a picture of the goose intestinal microbiota that is characterized by $16 \mathrm{~S}$ rRNA gene sequences indicative of many genera and species, yet at a higher phylogenetic level, relatively few of the bacterial groups are represented. The data will be useful for future studies related to competitive exclusion and for experiments evaluating the impact of, for example, growth promoters, anticoccidial compounds or stress on the intestinal microbiota. Clearly, the choice of technique used to analyse the bacterial populations influenced the data obtained in this study, and even the choice of primer pairs made a difference. There is clearly a need to complement the earlier culture based data and the data generated with techniques based on PCR amplification with data that are independent of amplification bias, such as in situ hybridization.

\section{REFERENCES}

Barnes E.M., 1979. The intestinal microflora of poultry and game birds during life and after storage. J. Appl. Bacteriol. 46, 407-419 
Gong J.H., Forster R.J., Yu H., Chambers J.R., Wheatcroft R., Sabour P.M., Chen S., 2002. Molecular analysis of bacterial populations in the ileum of broiler chickens and comparison with bacteria in the caecum. Microbial Ecol. 41, 171-179

Kawai M., Matsutera E., Kanda H., Yamaguchi N., Tani K., Nasu M., 2002. 16S ribosomal DNAbased analysis of bacterial diversity in purified water used in pharmaceutical manufacturing processes by PCR and denaturing gradient gel electrophoresis. Appl. Environ. Microbiol. 68, 699-704

Maniatis T., Fritsch E.F., Sambrook J. (Editors), 1989. Molecular Cloning: a Laboratory Manual. $2^{\text {nd }}$ Edition. Cold Spring Harbor Laboratory, NY

Muyzer G., Waal E.C., Uitterlinden A.G., 1993. Profiling of complex microbial populations by denaturing gradient gel electrophoresis analysis of polymerase chain reaction-amplified genes coding for 16SrRNA. Appl. Environ. Microbiol. 59, 695-700

Orisini M., Romano-Spica V., 2001. A microwave - based method for nucleic acid isolation from enviroment samples. Lett. Appl. Microbiol. 35, 17-20

Ovreas L., Forney L., Daae F.L., Torsvik V., 1997. Distribution of bacterioplankton in meromictic Lake Saelevannet, as determined by denaturing gradient gel electrophoresis of PCR-amplified gene fragments coding for 16SrRNA. Appl. Environ. Microbiol. 63, 3367-3373

Pedroso A.A., Menten J.F.M., Lambais M.R., 2005. The structure of bacterial community in the intestines of newly hatched chicks. Poultry Sci. 14, 232-237

Rahner R., 1901. Bakteriologische Mitteilungen über die Darmbakterien der Huehner. Zbl. Bakt. Parasitenk. 80, 239-244

Reeson A.F., Jankovic T., Kasper M.L., Rogers S., Austin A.D., 2003. Application of 16S rDNADGGE to examine the microbial ecology associated with a social wasp Vespula germanica. Insect Mol. Biol. 12, 85-91

Robinson I.M., Allison M.J., 1981. Characterizations of the cecal bacteria of normal pigs. Appl. Environ. Microbiol. 41, 950-955

Scupham A.J., Presley L.L., Wei B. et al., 2006. Abundant and diverse fungal microbiota in the murine intestine. Appl. Environ. Microbiol. 72, 793-801

Shapiro S.K., Sarles W.B., 1949. Microorganisms in the intestinal tract of normal chickens. J. Bacteriol. 58, 531-544

Theunissen J., Britz T.J., Torriani S., Witthuhn R.C., 2005. Identification of probiotic microorganism in South African products using PCR-based DGGE analysis. Int. J. Food Microbiol. 98, 11-21

Torok V.A., Ophel-Keller K., Loo M., Hughes R.J., 2008. Application of methods for identifying broiler chicken gut bacterial species linked with increased energy metabolism. Appl. Environ. Microbiol. 74, 783-791

Xiao W., Peng Q., Liu H.W., Wen M.L., Cui X.L., 2007. Prokaryotic microbial diversity of the ancient salt deposits in the Kunming Salt Mine, P.R. China. Acta. Microbiol. Sinica 47, 295300

Yu Z.T., Morrison M., 2004. Comparisons of different hypervariable regions of rrs genes for use in fingerprinting of microbial communities by PCR-denaturing gradient gel electrophoresis. Appl. Environ. Microbiol. 70, 4800-4806

Zhang M.A., Wang B.W., Long F.Y., Wang L., Yang Z.G., Zhang X.H., Liu G.L., 2007. Effect of different fibre level diets on normal microbiological floras in goose intestines. J. Fujian Agr. Forest. Univ. 36, 159-162

Zhu X.Y., Zhong T.Y., Pandya Y.G., Joerger R.D., 2002. 16SrRNA-based analysis of microbiota from the caecum of broiler chickens. Appl. Environ. Microbiol. 68, 124-137 